\title{
HUBUNGAN PENGUASAAN KOSAKATA DENGAN KEMAMPUAN MENULIS CATATAN HARIAN PADA SISWA KELAS VII SMP NEGERI 1 PULOSARI KABUPATEN PANDEGLANG
}

\author{
Meliyawati, M.Pd ${ }^{1}$ Lina Marlia Dewi, M.Pd ${ }^{2}$ Yeni Sulaeman $^{3}$ \\ meliyawati3@gmail.com
}

UNMA Pandeglang Banten Indonesia, Universitas Serang Raya, STKIP Syekh

Manshur

\begin{abstract}
Abstrak. Hubungan Penguasaan Kosakata Dengan Kemampuan Menulis Catatan Harian Siswa Kelas VII SMP Negeri 1 Pulosari Kabupaten Pandeglang. Metode yang digunakan dalam penelitian ini adalah metode deskriptif dengan teknik korelasi yang dilakukan di SMP Negeri 1 Pulosari Kabupaten Pandeglang. Adapun teknik sampel menggunakan Proportionate Stratifie Random Sampling. Jumlah siswa yang dijadikan sampel adalah 38 orang. Berdasarkan pengolahan data didapat nilai tes penguasaan kosakata siswa kelas VII SMP Negeri 1 Pulosari Kabupaten Pandeglang cukup. Sedangkan kemampuan menulis catatan harian siswa kelas VII SMP Negeri 1 Pulosari Kabupaten Pandeglang sudah baik. Hasil pengujian hipotesis diketahui bahwa terdapat hubungan yang positif antara penguasaan kosakata (X) dengan kemampuan menulis catatan harian (Y). Maka hipotesis penguasaan kosakata dengan kemampuan menulis catatan harian pada siswa kelas VII SMP Negeri 1 Pulosari Kabupaten Pandeglang, dapat diterima. Hal ini dapat dibuktikan dengan melakukan uji $\mathrm{t}$ di mana hasil perhitungan statistik diperoleh nilai uji $\mathrm{t}$ sebesar 16,309 . Nilai $\mathrm{t}_{\text {hitung }}$ ini lebih besar dari pada nilai $t_{\text {tabel }}$ yaitu 16,09 > 2,048. Kedua hubungan ini memiliki pola yang linier dan dinyatakan dengan persamaan regresi $\hat{Y}=25,915+0,658 \mathrm{X}$.
\end{abstract}

Kata Kunci: Penguasaan Kosa Kata dan Kemampuan Menulis Catatan Harian

Abstract. The relationshop of vocabulary mastery with writing diarieses of seventh grade students of SMP Negeri 1 Pulosari, Pandeglang Regency. The method is descriptive method with the correlation technique carried out at SMP Negeri 1 Pulosari, Pandeglang Regenczy.As for the sample technique using Proportionate Stratifie Random Sampling. Tehe number of students sample was 38 people. Based on data processing, it was found that the vocabulary masterz test scores of the VII grade students of SMP Negeri 1 Pulosari, Pandeglang Regency were sufficient. While the ability to write daily notes for seventh grade students of SMP Negeri 1 Pulosari, Pandeglang Regency is good. The results oh hypothesis testing show that there is a positive relationship between vocabulary mastery $(X)$ and the ability to write daily notes $(Y)$. then the hypothesis of vocabulary mastery with the ability to write dailz notes in class VII students of SMP Negeri 1 Pulosari, Pandeglang Distric, can be accepted. This can be proven by doing the test where the results of statistical calculations obtained a test value of 16,309. The calculated tvalue is greather than the table value wich is 16,09 >2,048. Both of these relationships have a linier pattern and are expressed bY the regession equation $Y=25,915+0,658 X$.

Keywords : mastery of vocabulary, and the ability to write daily notes

\section{PENDAHULUAN}

Keterampilan mendengarkan dan keterampilan membaca merupakan keterampilan reseptif, sedangkan keterampilan berbicara dan keterampilan menulis merupakan keterampilan produktif. Keterampilan menulis merupakan salah satu keterampilan berbahasa di antara ketiga keterampilan yang lainnya. Menulis juga merupakan kegiatan yang sangat menyenangkan dan dapat memberikan motivasi bagi siswa yang mempelajari keterampilan menulis. Menulis bagi sebagian orang dianggap sebagai kebutuhan hidup, Sebuah tulisan kadang menjadi sebuah cerminan kepribadian dan pengetahuan seseorang. Tidak semua orang bisa menulis dengan benar, terkadang untuk menghasilkan sebuah tulisan singkat seseorang memerlukan waktu berjam-jam 


\section{HENTI ROHENTI}

\section{PENGARUH TEKNIK BRAINWRITING TERHADAP KETERAMPILAN MENULIS TEKS DESKRIPSI SISWA KELAS VII SMP NEGERI 1 CARINGIN KABUPATEN SUKABUMI}

bahkan berhari-hari. Hanya pengetahuan dan ketertarikan akan subyek tulisan yang akan menuntun anda untuk menghasilkan tulisan yang dimaksud.

Morsey (dalam Tarigan, 2004:4) menyatakan bahwa:

Menulis dipergunakan oleh orang terpelajar untuk mencatat/merekam, meyakinkan, melaporkan/memberitahukan dan mempengaruhi, maksud dan tujuan seperti itu hanya dapat dicapai dengan baik oleh orang-orang yang dapat menyusun pikirannya dan mengutarakannya dengan jelas, kejelasan ini tergantung pada pikiran, organisasi, pemakaian kata-kata, dan struktur kalimat.

Pendapat Morsey di atas memberikan gambaran bahwa selain kemampuan menulis sangat penting untuk dikuasai, ternyata kemampuan menulis tidak sederhana yang dibayangkan. Hal ini disebabkan kemampuan menulis menghendaki penguasaan unsur kebahasaan dan unsur luar bahasa itu sendiri yang akan menjadi isi karangan, baik unsur bahasa maupun unsur isi haruslah terjalin sedemikian rupa sehingga menghasilkan karangan yang runtut dan padu.

Penulisan cacatan harian bisa dijadikan sebagai ajang latihan dalam menulis jenis-jenis tulisan lainnya. Kepiawaian menulis catatan harian akan berdampak pada kesanggupan seseorang dalam membuat tulisan lainnya. Ketidakmampuan siswa dalam menulis sebuah catatan harian bisa diakibatkan oleh berbagai faktor, diantaranya adalah minimnya penguasaan kosakata.

Secara teoretis, guna meningkatkan kemampuan menulis catatan harian perlu adanya peningkatan penguasaan kosakata yang memadai. Siswa yang memiliki kosakata yang banyak akan semakin mampu menulis catatan harian dengan baik pula. Namun kenyataan di lapangan menunjukkan teori tersebut tidak sesederhana demikian. Terdapat diantaranya siswa yang memiliki tingkat penguasaan kosakata yang cukup tinggi namun kurang menguasai penulisan catatn harian. Tetapi terdapat pula siswa yang penguasaan kosakata kurang bagus namun siswa tersebut cukup baik dalam penulisan catatan hariannya. Kenyataan inilah yang menggelitik penulis untuk melakukan penelitian lebih lanjut.

\section{METODE PENELITIAN}

Metode penelitian yang digunakan dalam penelitian ini adalah metode deskriptif, dengan teknik korelasional. Metode ini dimaksudkan untuk memperoleh gambaran tentang hubungnan penguasaan kosakata dengan kemampuan menulis catatan harian. Dalam menggunakan metode ini peneliti berusaha mengumpulkan data, mengklasifikasikan data, memaparkan data, menganalisis data, dan memberikan simpulan hasil analisis data.

Sejalan dengan metode yang digunakan dalam penelitian ini peneliti menggunakan teknik tes. Teknik tes ini dimaksudkan untuk memperoleh data tentang penguasaan kosakata dan kemampuan menulis catatan harian. Langkah-langkah penggunaan teknik ini adalah: (a) menyusun kisi-kisi tes, (b) menyusun instrument tes, (c) memberikan tes, (d) menganalisis hasil tes. Penelitian yang penulis lakukan terdiri dari dua variabel, yaitu Penguasaan Kosakata (Variabel X) dan Kemampuan Menulis Catatan Harian (variabel Y). Untuk memperoleh data penelitian dua variabel ini, penulis menyusun instrumen yang dikembangkan berdasarkan definisi konseptual, definisi operasional, serta penilaian masing-masing variabel.

\section{A. Teknik Analisis Statistik Deskriptif}

Teknik analisis data dalam penelitian kuantitatif menggunakan statistik. Analisa data yang dimaksudkan adalah untuk uji prasyarat dan uji hipotesis, yaitu menguji persyaratan analisis dan menguji hipotesis nol (Ho). Untuk itu data yang terkumpul akan dianalisis dengan bantuan teknik statistik deskriptif. Tabulasi data merupakan analisis tahap awal untuk mendeskripsikan data. Tabel yang digunakan adalah tabel frekuensi relatif.

\section{HASIL DAN PEMBAHASAN \\ 1. Hasil Penelitian}

\section{Deskripsi Hasil Tes Penguasaan Kosakata}

Berdasarkan data hasil tes penguasaan kosakata, maka diperoleh nilai tertinggi 88 dan nilai terendah 44 . Rata-rata hitung kelompok tes ini sebesar 66,03; median sebesar 66,38; dan modus sebesar 70,7 ;

Tabel 1

Persebaran Nilai Tes Penguasaan Kosakata

\begin{tabular}{|c|c|c|c|}
\hline $\begin{array}{c}\text { Rata- } \\
\text { rata } \\
\text { Hitung }\end{array}$ & Median & Modus & $\begin{array}{c}\text { Simpangan } \\
\text { Baku }\end{array}$ \\
\hline 66,03 & 66,38 & 70,7 & 12,07 \\
\hline
\end{tabular}




\section{HENTI ROHENTI}

\section{PENGARUH TEKNIK BRAINWRITING TERHADAP KETERAMPILAN MENULIS TEKS DESKRIPSI SISWA KELAS VII SMP NEGERI 1 CARINGIN KABUPATEN SUKABUMI}

\section{Deskripsi Hasil Tes Kemampuan Menulis Catatan Harian}

Berdasarkan hasil tes kemampuan menulis catatan harian, maka diperoleh nilai tertinggi 90 dan nilai terendah 50 . Rata-rata hitung sebesar 69,58; median 68,61; dan modus 66,58. Pengelompokan nilai tes kemampuan menulis catatan harian siswa hasil penelitian dapat di lihat pada tabel di bawah ini.

Tabel 2

Persebaran Nilai Tes Menulis Catatan Harian

\begin{tabular}{|c|c|c|c|}
\hline $\begin{array}{c}\text { Rata- } \\
\text { rata } \\
\text { Hitung }\end{array}$ & Median & Modus & $\begin{array}{c}\text { Simpangan } \\
\text { Baku }\end{array}$ \\
\hline 69,58 & 68,61 & 66,58 & 10,22 \\
\hline
\end{tabular}

Berdasarkan tabel di atas dapat dijelaskan bahwa terdapat 27 responden atau $71,04 \%$ siswa memiliki kemampuan menulis catatan harian cukup karena berada pada rentang nilai di atas 63 dan hanya 11 siswa atau 28,96\% yang masih kurang dalam kemampuan menulis catatan harian.

Tabel 3

Tabel Bantu Uji Homogenitas

\begin{tabular}{|l|c|c|}
\hline \multirow{2}{*}{$\begin{array}{c}\text { Nilai } \\
\text { Varians } \\
\text { Sampel }\end{array}$} & \multicolumn{2}{|c|}{ Hubungan } \\
\cline { 2 - 3 } & $\begin{array}{c}\text { Penguasaan } \\
\text { kosakata }\end{array}$ & $\begin{array}{c}\text { Kemampuan } \\
\text { menulis } \\
\text { catatan } \\
\text { harian }\end{array}$ \\
\hline Rata-rata & 66,03 & 69,58 \\
\hline $\mathrm{S}^{2}$ & 145,66 & 104,41 \\
\hline $\mathrm{S}$ & 12,07 & 10,22 \\
\hline $\mathrm{N}$ & 38 & 38 \\
\hline
\end{tabular}

Berdasarkan tabel di atas, maka dapat dilakukan perhitungan dan hasilnya $F_{\text {hitung }}$ sebesar 1,395 dan $F_{\text {tabel }}$ pada $\alpha=0,05$ dengan $\mathrm{db}$ penyebut 37 dan pembilang 37 diperoleh angka sebesar 1,7275 maka $F_{\text {hitung }} \leq F_{\text {tabel }}$ dengan demikian maka data homogen.

\section{Pembahasan}

Berdasarkan hasil analisis secara statistik, maka di bawah ini akan dikemukakan interprestasi hasil analisis data. Hasil pengujian $\mathrm{H}_{1}=\mathrm{r}_{\mathrm{xy}}>0$ dengan rumus Pearson Product Moment Correlasion dan rumus uji $\mathrm{t}$ menyatakan bahwa ada hubungan yang signifikan antara penguasaan kosakata dengan kemampuan menulis catatan harian, yang memiliki koefisien sebesar $r_{x y}=0,731$ sedangkan $\mathrm{r}_{\text {tabel }}$ untuk jumlah sampel 38 orang siswa pada taraf signifikasi $\alpha=0,05$ sebesar 0,329 ternyata $r_{\text {hitung }}$ lebih besar dari $r_{\text {tabel }}$, maka hipotesis nol (Ho) berhasil ditolak. Hal ini menunjukkan pula oleh besarnya koefisien korelasi hasil uji signifikasi (Uji t) pada taraf signifikasi $\alpha=0,05$ dan derajat kebebasan (dk) 36, yaitu $t_{\text {hitung }}=16,309$, sedangkan pada tabel menunjukkan $\mathrm{t}_{\text {tabel }}=$ 2,048 ternyata $t_{r}$ lebih besar daripada $t_{t}$ (perhitungan tercantum dalam lampiran 10).

Pola hubungan antara kedua variabel tersebut dinyatakan dengan persamaan $\hat{\mathrm{Y}}=25,915+0,658 \mathrm{X}$. Persamaan ini memberikan informasi bahwa setiap perubahan satu unit penguasaan kosakata akan dapat mengakibatkan terjadinya perubahan pada kemampuan menulis catatan harian sebesar 0,658 pada konstanta 25,915 .

Ditolaknya hipotesis nol (Ho) berarti hipotesis $\left(\mathrm{H}_{1}\right)$ yang menyatakan ada hubungan yang signifikan antara penguasaan kosakata dengan kemampuan menulis catatan harian dapat diterima. Hal ini berarti pula bahwa siswa yang memiliki tingkat penguasaan kosakata yang tinggi pada umumnya mempunyai kemampuan menulis catatan harian yang tinggi pula atau sebaliknya, jika siswa memiliki penguasaan kosakata rendah maka siswa tersebut akan memiliki kemampuan menulis catatan harian yang rendah pula.

Berdasarkan hasil analisis data penelitian dapat disimpulkan bahwa untuk dapat memiliki tingkat kemampuan menulis catatan harian yang baik diperlukan penguasaan kosakata yang baik pula.

\section{SIMPULAN}

1. Hasil pengujian hipotesis diketahui bahwa terdapat hubungan yang positif antara penguasaan kosakata (X) dengan kemampuan menulis catatan harian (Y). Hal ini ditunjukan oleh indeks korelasi penelitian sebesar 0,731. sedangkan angka tabel untuk 38 siswa menunjukan indeks 0,329. Dengan demikian, nilai koefisien korelasi lebih besar daripada nilai yang terdapat dalam tabel. Hal ini berarti sekaligus pula menolak hipotesis nol. Maka hipotesis penguasaan kosakata dengan kemampuan menulis catatan harian pada siswa kelas VII SMP Negeri 1 Pulosari Kabupaten Pandeglang dapat 


\section{HENTI ROHENTI}

PENGARUH TEKNIK BRAINWRITING TERHADAP KETERAMPILAN MENULIS

TEKS DESKRIPSI SISWA KELAS VII

SMP NEGERI 1 CARINGIN KABUPATEN SUKABUMI

diterima. Kedua variabel ini memiliki tingkat hubungan yang tinggi karena berada pada rentang $0,70-0,89$ sehingga dapat dinyatakan bahwa hubungannya sangat signifikan. Hal ini dapat dibuktikan dengan melakukan uji $\mathrm{t}$ di mana hasil perhitungan statistik diperoleh nilai uji t sebesar 16,309. Nilai $t_{\text {hitung }}$ ini lebih besar dari pada nilai $t_{\text {tabel }}$ yaitu $16,09>2,048$. Kedua hubungan ini memiliki pola yang linier dan dinyatakan dengan persamaan regresi $\hat{Y}=25,915+0,658 \mathrm{X}$.

\section{SARAN}

1. Untuk meningkatkan penguasaan kosakata dan kemampuan menulis catatan harian diperlukan peningkatan pembelajaran memahami cara bagaimana meningkatkan penguasaan kosakata dan kemampuan menulis catatan harian yang benar, baik secara kuantitatif maupun kualitatif.

2. Mengingat penguasaan kosakata sangat erat hubungan kemampuan menulis catatan harian, maka hendaknya semakin ditingkatkan kualitasnya, yaitu dengan cara guru harus dapat memilih bahan pembelajaran yang cocok bagi perkembangan jiwa siswa. Bahan pembelajaran tidak harus selalu teori tentang menulis catatan harian saja akan tetapi bisa juga bahan pembelajaran tentang aspek kebahasaan lainnya yang mendukung kepada kemampuan menulis catatan harian siswa. Hal ini untuk meningkatkan konsentrasi siswa dalam menulis catatan harian dan dapat pula menunjang materi pelajaran yang lain. Oleh karena itu, hendaknya penguasaan kosakata dan kemampuan menulis selalu menyatu dengan proses belajar mengajar. Penguasaan kosakata sebagai salah satu teknik menulis catatan harian lanjut dan penguasaan kosakata sebagai proses berpikir menerima informasi yang diperlukan oleh semua disiplin ilmu.

\section{DAFTAR PUSTAKA}

Alwi, Hasan. 2001. KBBI. Pusat Bahasa Departemen Pendidikan Nasional. Jakarta: BR.

Keraf, Gorys. 2004. Argumentasi dan Narasi. Jakarta: PT. Gramedia Pustaka.

Merriam-Webster. (2011). Kezword Definition. Merriam Webster Online Dictonary.
Ramlan, M. 2001. Ilmu Bahasa Indonesia: Paragraf. Yogyakarta: CV. Karyono.

Semi, Atar. 2007. Dasar-dasar Keterampilan Menulis. Bandung: Angkasa

Suparno dan Yunus. 2008. Keterempilan Dasar Menulis. Jakarta: Universitas Terbuka.

Tarigan, H.G. 2008. Menulis Sebagai Suatu Keterampilan Berbahasa. Bandung: Angkasa

Zainurrahman. 2013. Menulis Dari Teori Hingga Pratek. Bandung : Alfabeta. 